증 례

\title{
$\mathrm{SIADH}$ (항이뇨호르몬 부적절분비증) 를 동반한 세균성 폐렴 1 예
}

\author{
부산대학교 의과대학 내과학교실 \\ 박 현-정 원 태-이 민 기 \\ 강 영 진·박 순 규·신 영 기
}

$=$ Abstract $=$

\section{A Case of Bacterial Pneumonia Associated with SIADH}

\author{
Hyun Park, M.D., Won Tae Chung, M.D., Min Ki Lee, M.D. \\ Yeong Jin Kang, M.D., Soon Kew Park, M.D. and Yeong Kee Shin, M.D.
}

Department of Internal Medicine, College of Medicine, Pusan National University, Pusan, Korea

The syndrome of inappropriate $\mathrm{ADH}$ secretion (known as SIADH) is characterized by hyponatremia that result from watr retention attributable to inappropriate or excessive secretion of ADH.

SIADH was originally described by Schwartz in 1957. It was more fully characterized by Bartter and Schwartz in 1967, and it is now well known that inappropriate ADH secretion may be associated with the disease process of host including CNS disorders, pulmonary diseases, endocrine disorders. It may be also be secondary to medications and tumors, notably bronchogenic carcinoma of the 'oat' cell type.

We experienced a case of bacterial pneumonia associated with SIADH who had admitted with dyspnea and chest pain. The bacterial pneumonia was diagnosed by chest $\mathrm{P}-\mathrm{A}$, chest $\mathrm{CT}$, and sputum culture and treated with antibiotics. Also SIADH was diagnosed from hyponatremia, increased urinary sodium excretion, high urine osmolality than that of plasma, and exclusion of other causes of hyponatremia and treated with hypertonic solution and water restriction.

Described here a case of bacterial pneumonia associated with SIADH with some review of literature.

서 론

항이노호르몬 분비이상증 (Syndrome of inappropriate $\mathrm{ADH}$ Secretion, 이하 SIADH로 약기)은 혈 청 내 저나트륨증임에도 불구하고 부적절하게 $\mathrm{ADH}$ 가 분비됨 으로 인한 수분축적의 결과로써 야기되는 저나트륨혈증 을 특징으로 하는 증후군이다 ${ }^{125}$.

1957년에 Schwartz등(6)이 폐암환자에서 동반된
$\mathrm{SIADH}$ 를 처음 보고한 후, 현재까지 많은 예가 보고된 바가 있다 ${ }^{73)}$. 우리나라에서도 SIADH가 많이 있을 것 으로 예상되나 이에 대한 보고는 그렇게 흔치 않다. 1976 년 강 등 ${ }^{14)}$ 이 $\mathrm{SIADH}$ 가 강력히 의심되는 12 예의 환자를 보고한 것을 처음으로 그후 드물게 보고되어 왔다 ${ }^{15 ~ 19)}$. 저자들은 본 병원 내과에 흥부동통과 호흡곤란을 주소 로 입원하여 세균성 폐렴으로 진단된 50 세 남자 환자에 서 SIADH가 동반된 것을 경험하였기에 문헌고찰과 함 께 그 증례를 보고하는 바이다. 
증

\section{改}

환 자 : 김 00,50 세, 농부.

주 소 : 호흡곤란 및 훙부동통.

현병력 : 환자는 상기주소가 발생하기 약 1 개월전부터 전신적 동통 및 기침이 발생하였는데 약국에서 신경통과 늑막염이라는 말을 듣고 약물을 복용하며 집에서 누워지 냈다고 한다. 약 10 일전부터 호흡곤란과 흥부동통이 발 생하여 약 3 일전 모개인병원을 방문한 후 치료받았으나 증세가 악화되어 본원으로 전원되었다.

과거력 : 특이사항 없음.

가족력 : 특이사항 없음.

사회력 : 심한 주벽을 가짐 (하루에 소주 1병 정도를 마 신다고 함).

이학적 소견 : 내원당시 혈압은 $90 / 60 \mathrm{mmHg}$, 맥박수 는 104 회/분, 액와체온은 $36.4^{\circ} \mathrm{C}$, 호흡수는 28 회/분이었 다. 환자는 전신적으로 쇠약해 보였고, 약간 탈수된 것 처럼 보였다. 흉부검진상 좌폐야에 걸쳐 전반적으로 감 소된 호흡음 및 수포음이 들렸으며 동성빈맥이 감지되었 으나 심잡음은 없었다. 복부검진상 간장이 촉지되었으며

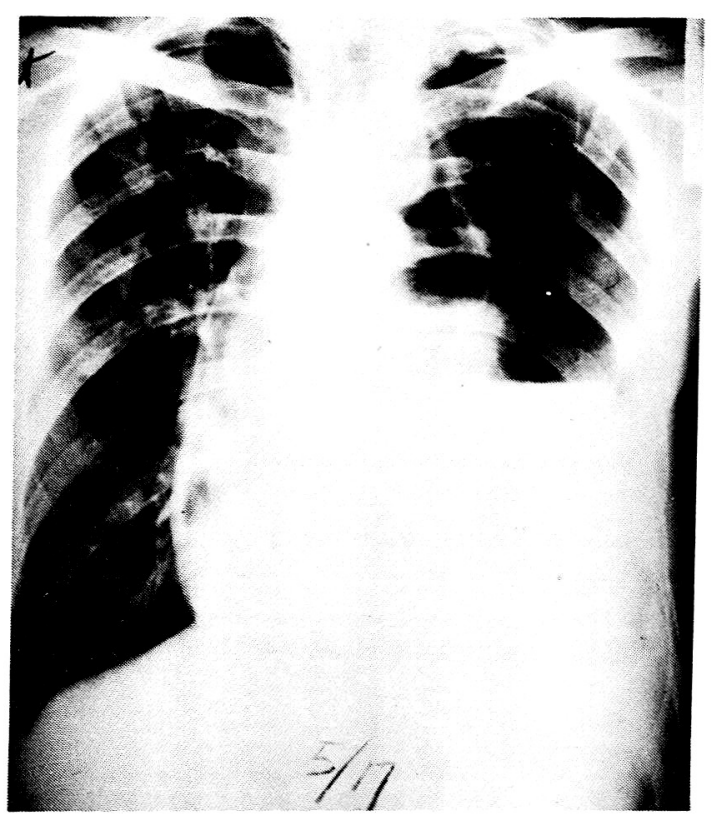

그림 1. 단순 흉부 촬영상 : 좌폐야에 흉막삼출액 및 우 폐야에 소량의 훙막삼출액
가벼운 압통을 호소하였다. 하지에 경도의 부종이 감지 되었다. 그이외의 특이한 이학적 소견은 없었다.

검사실 소견 : 말초혈액 소견상 중등도의 백혈구증다증 $\left(27,400 / \mathrm{mm}^{3}\right)$ 을 보였고, 뇨검사는 정상이었다. 혈청전 해질검사상 $\mathrm{Na}$ 가 감소 $(121.5 \mathrm{mM} / \mathrm{L})$ 되어 있었으며, $\mathrm{Cl}$ 도 감소 $(86.9 \mathrm{mM} / \mathrm{L})$ 되어 있었으나 다른 전해질은 정상 범위내에 있었다. 간기능 검사상 SGOT $345, \mathrm{SGPT}$ 329, Alkaline Phaos phatase 171, $\gamma$-GTP $164 \mathrm{IU} / \mathrm{L}$, Globulin $4.1 \mathrm{gm} / \mathrm{dl}$ 로 증가되어 있었으며 Albumin과 Cholesterol은 각각 $2.1 \mathrm{gm} / \mathrm{dl}$ 및 $94 \mathrm{mg} / \mathrm{dl}$ 로 감소되어 있었다.

신기능검사소견은 정상이었다. 심전도검사상 동성빈 맥과 저전압을 보였다. $\mathrm{B}$ 형간염 항원항체검사상 $\mathrm{HBsAg}(+), \mathrm{HBeAg}(+), \mathrm{HBcAb}(+)$ 였다. 갑상선기능 검사는 혈청내 $\mathrm{T}_{3} 120 \mathrm{ng} / \mathrm{dl}, \mathrm{F}-\mathrm{T}_{4} 1.5 \mathrm{ng} / \mathrm{dl}, \mathrm{TSH} 2.0$ $\mu \mathrm{IU} / \mathrm{ml}$ 로 정상소견이었고, 부신기능검사는 혈청내 Cortisolo이 $18 \mu \mathrm{g} / \mathrm{dl}(8 \mathrm{AM})$ 과 $9 \mu \mathrm{g} / \mathrm{dl}(4 \mathrm{PM})$, aldosterone이 $4 \mu \mathrm{g} / \mathrm{dl}$ 로 정상소견을 보였다. 단순흥부 $\mathrm{X}$-선 촬영상(Fig. 1) 및 홍부단층찰영상 (Fig. 2)에서 좌폐야 에 다수의 구획된 수기흥증 및 흉막삼출액과 실질성폐렴, 우폐야에 소량의 흉막삼출액, 및 심낭삼출액을 보였다.

단순복부 X-선촬영상에서는 간장종대를 제외하고는 특이한 소견은 없었다. 객담배양검사상 황색포도상구균 및 Klebsiella균이 자랐다. 객담세포검사 (7회시행) 상 악 성세포는 검출되지 않았다. 혈청 $\mathrm{AFP}$ 와 $\mathrm{CEA}$ 치는 정상 이었다.

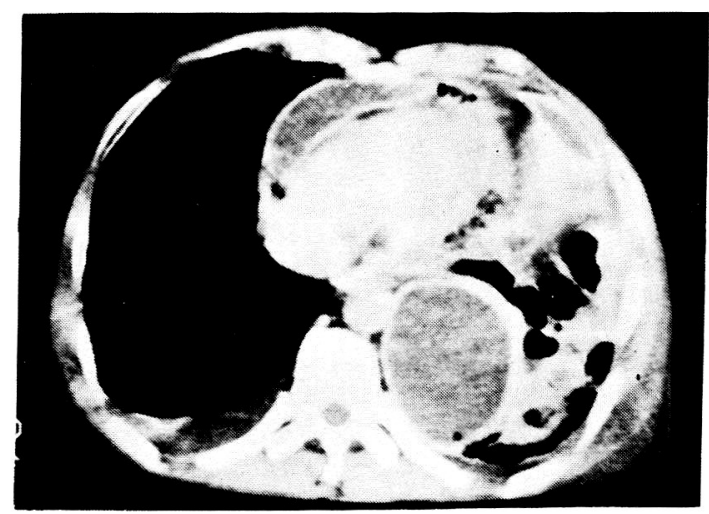

그림 2. 훙부 단층 촬영상 : 가예야에 수기홍증 및 훙막 삼출액 실질성 폐렴 좌폐야에 소량의 훙막 삼출 액 
Table 1. 입원경과중 혈청 및 소변 $\mathrm{Na}$ 농도 및 삼투압변화

\begin{tabular}{cccccc}
\hline \hline Hospital day & $\begin{array}{c}\text { WBC } \\
\left(/ \mathrm{mm}^{3}\right)\end{array}$ & $\begin{array}{c}\text { Serum Na } \\
(\mathrm{mM} / \mathrm{L})\end{array}$ & $\begin{array}{c}\text { Urine Na } \\
(\mathrm{mM} / \mathrm{L})\end{array}$ & $\begin{array}{c}\text { Serum Osm } \\
(\mathrm{mOsm} / \mathrm{kg})\end{array}$ & $\begin{array}{c}\text { Urine Osm } \\
(\mathrm{mOsm} / \mathrm{kg})\end{array}$ \\
\hline & 27400 & 121.5 & 92.3 & 267 & 629 \\
& 24200 & 115.2 & 73.4 & 230 & 715 \\
& 21300 & 108.1 & 66.7 & 210 & 806 \\
3 & 20100 & 111.6 & 88.2 & 213 & 567 \\
& 22800 & 116.4 & 30.5 & 225 & 687 \\
& 12400 & 128.9 & 117.2 & 246 & 507 \\
5 & 10900 & 132.7 & 165.1 & 259 & 598 \\
6 & 13000 & 150.1 & 169.7 & 298 & 529 \\
7 & 10200 & 122.3 & 152.9 & 262 & 396 \\
8 & 9700 & 133.8 & 130.5 & 318 & 837 \\
9 & 8500 & 131.2 & 198.1 & 254 & 675 \\
10 & 8400 & 132.6 & 206.7 & 257 & 819 \\
11 & 8700 & 131.9 & 182.0 & 258 & 804 \\
\hline
\end{tabular}

: Water restriction $(<1 \mathrm{~L} /$ day $)$ \& hypertonic sodium solution

: partial release of water restriction ( $1-2 \mathrm{~L} /$ day)
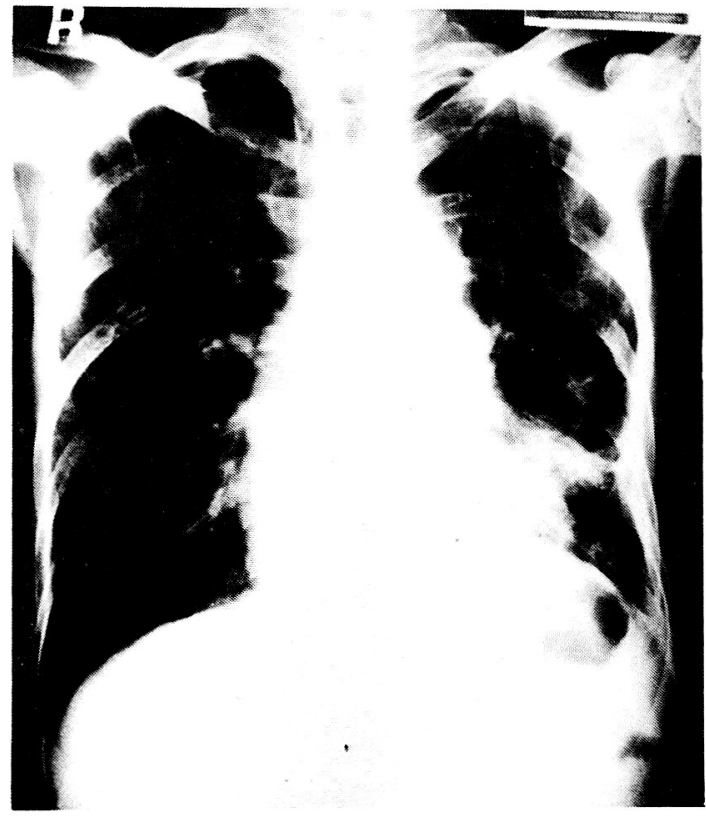

그림 3. 단순 훙부 촬영상 : 좌폐야의 훙막삼출액 및 실 질성 폐렴의 호전

입원경과 : 입원즉시 폐쇄적 훙부삽관술을 시행하였으 며 늑막삼출액검사는 exudate 소견을 보였다. 입원 2일

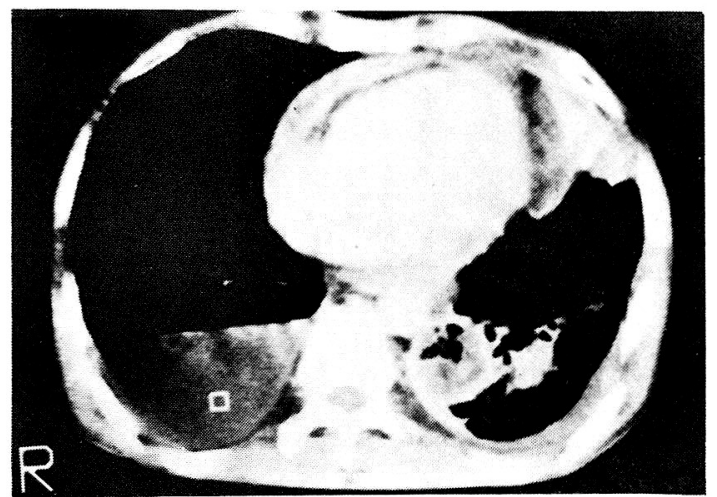

그림 4. 흥부 단층 찰영상 : 좌폐야 수기훙증 및 훙막삼 출액 실질성 폐렴의 호전 우 폐야에 훙막삼출액

째 두통, 오심, 및 구토를 호소하였으며 혈중 $\mathrm{Na}$ 치가 더 떨어졌다. 이때부터 SIADH를 의심하여 수분섭취제한과 동시에 계속적인 혈청 및 소변내 나트륨과 삼투압측정을 시작하였다. 입원 10 일경에는 혈청 나트륨치가 정상범위 로 돌아왔고, 저나트륨혈증으로 인한 증상들이 호전되었 다. 그동안의 검사실적 경과는 Table 1 과 같다. 갑상선 및 부신기능은 검사상 정상으로 나타났다. 항생제 감수 성 검사결과에 따라 폐렴에 대한 항생제 요법과 동시에 대증요법을 시행한 결과 입원 14 일경부터는 상당한 증세 
호전을 보였으며 퇴원 당시 (제25병일째) 촬영한 흉부단순 X-선촬영상 (Fig. 3) 및 흥부전산화단촬영상 (Fig. 4)에서 좌폐하부에 걸친 경도의 폐실질침윤 및 소량의 국한된 삼 출을 제외하고는 현저하게 호전된 소견을 보였으며 간기 능검사에서도 많은 호전을 보였다.

\section{고 찰}

Schwartz등 ${ }^{20)}$ 에 의하면 SIADH의 특징적인 소견으 로서 다음의 6가지 조건을 제시하고 이에 부합되는 경우 에만 SIADH라고 하였다.

즉 1) 저나트륨혈증과 혈장내 삼투압저하, 2) 신장에 서의 지속적인 염분소실, 3) 혈액용적의 부족이 없을 것, 4) 요중 삼투압이 혈중 삼투압보다 높을 것, 5) 신기능 이 정상, 6) 부신기능이 정상이 그것이다 ${ }^{1-4)}$.

$\mathrm{SIADH}$ 의 원인으로서는 1) 악성종양, 2) 비종양성 폐 질환, 3) 중추신경계질환, 4) 약물 등으로 대별한 다 ${ }^{14211}$.

$\mathrm{SIADH}$ 의 병태생리학적 기전을 살펴보면 다음과 같 다. 첫째로 $\mathrm{ADH}$ 가 종양세포들로부터 자율적으로 합성, 저장, 분비되는 것으로 폐장의 소세포상피암이 그 대표 적인 예이다. 둘째로 비종양성 폐조직에서 자율적으로 $\mathrm{ADH}$ 를 합성분비하던지 혹은 좌심방압을 감소시켜서 중 추적으로 $\mathrm{ADH}$ 분비를 촉진시키는 것이다. 폐결핵과 폐 렴이 그 대표적인 예이다. 세째로, 신경성 뇌하수체를 직 접 자극하여 $\mathrm{ADH}$ 를 분비시키는 것으로 중추신경계 염 증 및 약물등이 그 대표적인 예이다 1 4,22 26).

$\mathrm{SIADH}$ 의 증상은 저나트륨혈증과 동일한 것이다. 즉 권태감, 전신쇠약감, 근육통, 정신혼돈, 오심, 구토, 두 통, 발작 혼수 등이다 ${ }^{1 \sim 5}$.

$\mathrm{SIADH}$ 의 진단을 위해서는 혈중과 프중 나트륨농도 및 삼투압측정이 필수적이며 비슷한 증상 및 소견을 보이는 다른 질환 즉 1) 희석성저나트륨혈증(특히, 부신기능부 전, 염분소실성 신염, 설사, 이전의 이느제 요법), 2) 저 나트륨혈증성 부종상태 (울혈성심부전증, 간경화증, 신 증후군), 3) 가성저나트륨혈증(고지 질증과 연관됨), 4) 심한 고당혈증, 5) 갑상선 기능저하증, 6) 원발성 다음 다갈증, 7) 본태성 저나트륨혈증 등과의 감별진단이 필 요하다 ${ }^{12 ~ 14,25,26)}$. 물론 확진을 위해서는 혈중 $\mathrm{ADH}$ 측정 을 하면 된다 ${ }^{1-5,27)}$.

$\mathrm{SIADH}$ 치료에 관해 살펴보면 대부분의 경우 수분섭
취제한만으로 호전된다고 하나 때로는 고장성 $\mathrm{NaCl}$ 용 액이 필요하기도 하다. 물론 원인이 되는 기존질환이 예 후에 중요한 영향을 미칠 것이다. 일부에 있어서는 Demechlocycline, Lithium salt, Diphenylhydantoin 등이 효과를 나타낼 때도 있다고 한다 ${ }^{1 \sim 5,28 ~ 30)}$.

본 환자에서는 입원초부터 저나트륨혈증을 보였으며 특별한 약물복용이나 중추신경계 질환이 없고 악성종양 의 증거가 없으면서 부신 및 갑상선 기능도 정상이었다. 또한 혈액과 뇨중 나트륨 농도 및 삼투압이 수분섭취제 한으로 호전된 점으로 미루어 보아 SIADH의 진단 기준 과 일치하며 그 원인으로서는 세균성 폐렴이 강력히 시 사된다. 혈중 $\mathrm{AHD}$ 측정이 불가능하여 확진을 하지 못 한 것을 유감으로 생각하는 바이다.

저나트륨혈증은 임상에서 흔히 경험하는 것이고 이의 한가지 원인이 되는 $\mathrm{SIADH}$ 는 실제로 폐결핵 및 폐암 환 자가 많은 우리 나라에서는 관심을 가지면 많은 증례를 찾을 수 있을 것으로 사료된다. 또한 초기에 발견하여 적 절한 치료만 하면 충분히 막아줄 수 있는 합병증으로 생 각된다. 이로 인하여 혼수 및 심하면 사망까지 초래할 수 있다는 것을 고려해 볼때 이에 대한 많은 관심이 필요할 것으로 사료된다.

\section{결 론}

저자들은 세균성 폐렴 환자에서 $\mathrm{SIADH}$ 의 전형적인 소 견을 관찰하였기에 이에 문헌 고찰과 함께 보고하는 바 이다.

\section{REFERENCES}

1) Andreoli TE: Textbook of medicine, 17th Ed, p526, Philadelphia, WB Saunders Company 1985

2) Goldberger $\mathrm{E}$ : Inappropriate $\mathrm{ADH}$ secretion syndrome(SIADH), A primer of water electrolyte \& acid-base syndrome, 7th Ed, p65, Philadelphia, Lea \& Febiger 1986

3) Lavin N: Manual of endocrinology and metabolism, 1st Ed, p71, Boston/Toronto, Little, Brown and Company 1986

4) Streeten DHP, Moses AM, Miller M: Principles of internal medicine, 11th Ed, p1729, New York, McGraw-Hill Book Company 1987

5) Clift GV, et al: Syndrome of inappropriate 
vasopressin secretion. Arch Intern Med 118:453, 1966

6) Schwartz WB, Bennett W, Curelop S, Bartter FC: A Syndrome of renal sodium loss and hyponatremia probably resulting from the inappropriate secretion of antidiuretic hormone. Am J Med 23:529, 1957

7) Carter NW, Rector FC JR, Seldin DW: Hyponatremia in cerebral disease resulting from the inappropriate secretion of antidiuretic hormone. N Engl J Med 264:67, 1961

8) Stormont JM, Waterhouse C: Severe hyponatremia associated with pneumonia. Metabolism 11:1181, 1962

9) Hellman ES, Tschudy DP, Barrter FC: Abnormal electrolyte and water metabolism in acute intermit. tent porphyria. Am J Med 32:734, 1962

10) Ross EJ: Hyponatremic syndromes associated with carcinoma of the bronchus. Quart J Med 32:297, 1963

11) Williams MJ, Barnes RN, Sommers SC: Hyponatremia, antidiuretic hormone secretion and oat cell carcinoma of the lung. Dis Chest 44:95, 1963

12) Weiss $\mathrm{H}$, Katz S: Hyponatremia resulting from apparently inappropriate secretion of antidiuretic hormone in patients with pulmonary tuberculosis. Am Rev Respir Dis, 92:1965

13) Peltinger WA, Talner L, Ferris TF: Inappropriate secretion of antidiuretic hormone due to myxoedema. N Engl J Med 273:362, 1965

14) 강종명, 이홍규, 민헌기 : $\mathrm{ADH}$ 분비이상증 (SIADH) 에 대한 임상적 관찰. 대한내과학회지 19:889, 1976

15) 박귀봉, 정웅진, 김명식, 송정상, 이창홍, 최영길 : 항 이노 호르몬 부적절 분비증을 동반한 급성 간헐성 포 르피리아증 2예. 대한내과학회지 22:179, 1979

16) 최석구. 이오정, 김예회 : 급성심근경색증과 유사한 심 전도 변화와 $\mathrm{SIADH}$ 를 동반한 급성 간헐성 폴피리아 1예. 대한내과학회지 23:539, 1980

17) 이태원, 김시영, 김진우, 김영설, 김광원, 김선우, 최 영길 : 정상인, 항이노 호르몬 부적절 분비증후군, 요 붕증, 간경변증 및 인슐린 비의존성 당노병 환자에서 의 혈 장 Arginine vasopression 측정에 관한 연구. 대 한내과학회지 27:41, 1984

18) 길선연, 노재경, 김계남, 이순남, 경난호, 박이갑 :
$\mathrm{SIADH}$ 를 병발한 급성 간혈성 포르피리아증 1 예. 대 한내과학회지 28:141, 1985

19) 조규찬, 류재철, 김진천, 변홍수, 주우식, 허갑도 : Isolated hyperthyroxinemia가 관찰된 $\mathrm{SIADH}$ 를 동 반한 급성 간헐성 폴피리아증 1 예, 대한내과학회지 29 : 288, 1985

20) Bartter FC, Schwartz WB: The syndrome of inappropriate secretion of antidiuretic hormone. Am J Med 42:790, 1967

21) Kaye M: An investigation into the cause of hyponatremia in the syndrome of inappropriate secretion of antidiuretic hormone.

22) Goldberg M: Hyponatremia and the inappropriate secretion of antidiuretic hormone. Am J Med 35:293, 1963

23) Moses AM, et al: Pathoophysiologic and pharmacologic alterations in the release and action of ADH. Metabolism 25:1967

24) Robertson GL: The regulation of vasopresin function in health and disease. Rec Progr Hormone Res 33:1977

25) De Fronzo RA, Their SO: Pathophysiologic approach to hyponatremia. Arch Intern Med 140: 897, 1980

26) Reichlin S: The neurohypophysis. Physiological and clinical aspects. New York, Plenum, 1984

27) Miller M, et al: Recognition of partial defects in antidiuretic hormone secretion. Ann Intern Med 73: 1970

28) Cherrill DA, Stote RM, Birge JR, Singer I: Demeclocycline treatment in the syndrome of inappropriate antidiuretic hormone secretion. Ann Intern Med 83: 654,1975

29) Forrest JN, et al: Superiority of demeclocycline over lithium in the treatment of chronic inappropriate secretion of antidiuretic hormone. N Engl J Med 298:173, 1978

30) Decaux G, et al: Hyponatremia in the syndrome of inappropriate secretion of antidiuretic hormone. Rapid correction with Urea Sodium chloride and water restriction therapy. JAMA 247:471, 1982 